\title{
THE POWER OF A PARTNER TO CONFESS JUDGMENT AGAINST THE PARTNERSHIP IN PENNSYLVANIA.
}

Very early in this jurisdiction, Shippen, P. J., struck off the judgment, as to the non-assenting partner, on the ground that commercial expedience did not require that any one of the partners should have the implied authority to confess judgment against the partnership, ${ }^{1}$ and his conclusion was subsequently upheld by Chief Justice Gibson. ${ }^{2}$ And so run a long unbroken line of decisions for more than a century ${ }^{3}$ until the Supreme Court decided the case of Boyd v. Thompson and Coxe, ${ }^{4}$ in which the court apparently holds that while the non-assenting partner is not liable individually, the partnership itself is liable. This doctrine was new to the law and to substantiate such a conclusion, the court introduced the "entity" theory of partnership. They treated the partnership as a distinct "creature," separate and apart from the personality of the individuals constituting such partnership, the effect of which appeared to overrule the earlier decisions of Judge Shippen and Chief Justice Gibson.

If the introduction of the "entity" theory in Boyd v. Thompson and Coxe had rested with that case and gone no further, then, perhaps, we would have had good grounds to consider the earlier cases of Girard v. Basse, ${ }^{5}$ Bitzer v. Shunk ${ }^{6}$ and Harper v. Fox ${ }^{7}$ as overruled. But we have the subsequent cases of Guckert v. Hacke $^{8}$ and Bank v. Crozell, ${ }^{9}$ in which the court held that the only way in which a partnership could relieve the separate

${ }^{2}$ Girard v. Basse, I Dallas, II9 (1784).

- Bitzer v. Shunk, I W. \& S. 340 (I84I), and Harper v. Fox, 7 W. \& S. 142 (1844).

${ }^{3}$ Down to McCleary v. Thompson, r3o Pa. 443 (1889). And it mattered little whether the partnership was indebted or not.

${ }^{4} 153 \mathrm{~Pa} .78$ (1893), and affirmed the same year in Franklin v. Morris, $154 \mathrm{~Pa} .152$.

'Supra, note I.

- Supra, note 2.

'Supra, note 2.

I59 Pa. 303 (1893).

I77 Pa. 313 (1896). 
members from individual liability is by conforming strictly with the Incorporation Act of $1874 .^{10}$ That is, a partnership carries with it the mantle of unlimited liability upon the shoulders of the separate individuals. And to divorce this partnership from such liability, the members of such partnership must conform strictly with the conditions imposed upon them by the legislature, which means that the "entity" is a legislative and not a judicial creation, and that the court is assuming upon the powers of the legislature when it attempts to create this separate "entity."

The decision of Boyd v. Thompson and Coxe was influenced by the conclusion of Justice Sharswood in Schmerz v. Schreeve, ${ }^{11}$ where it was decided that one partner could bind the partnership under a sealed instrument, if such partner had the implied authority to enter into such a contract. In that case, the seal would not vitiate a perfectly valid instrument. From this, the court, in Boy'd v. Thompson and Coxe concluded that a partner had the authority to bind the partnership by any instrument whatsoever under seal. Therefore, he could bind the partnership by a confession of judgment under seal. And this, notwithstanding the fact that at common law, no seal was necessary to confess judgment. ${ }^{12}$

The controlling feature in the minds of the judges appeared to be the fact that the confession of judgment was under seal. It seems that the more important question, whether the partner las the implied authority to confess such a judgment, was overlooked. Justice Sharswood laid especial emphasis upon the inherent or implied powers of which a partnership is endowed and limited his decision expressly to such conditions. A careful examination of the facts show that one partner entered into a contract "under seal," and in the firm name for the purchase of oil to be used in the partnership business. A contract of sale for the purchase of merchandise used by the co-partnership is clearly within the implied powers of the co-partnership, and, an act separate and distinct from the confession of judgment, as

${ }^{10}$ P. L. 73.

${ }^{11} 62 \mathrm{~Pa} .457$ ( 1869 ).

12 First National Bank of Hazleton v. Kintz, 24 Pa. Sup. Ct. 456 (1904). 
decided by Chief Justice Gibson. ${ }^{13}$ To that extent, Justice Sharswood's decision in Schmerz v. Schreeve ${ }^{14}$ is in line with all the decisions up to that time, and in fact, really does not take up the question of confession of a partnership judgment. The seeming error of the court in Boyd v. Thompson and Coxe lies in the fact that it gave to the decision in Schmers v. Schreeve, a much wider scope and meaning than Justice Sharswood really intencled it to convey.

The court's opinion in Boyd v. Thompson and Cove created considerable confusion in subsequent decisions. The Supreme Court is reluctant to follow this case and yet it is fettered to its conclusions. It is this feeling that causes the present undefined condition of the law on this subject. Especially is this true in dealing with the question of the distribution of such a fund. On the face of it, Boyd v. Thompson and Coxe would seem clearly wrong, but we venture that this is more apparent than real. As a matter of fact, the case is correct in its conclusion, but the decision must be sustained upon other grounds than that set out by the court. The real effect of the decision is, that for the purposes of execution, it sustains the judgment against the partnership, even though it exempts the non-assenting partner. Thus the court laid down a rule of practice confusing it with the more important question of substantive law by volunteering a reason for the former at the neglect of the latter. But fortunately, while the reasoning was in error, the conclusion was correct, as the same question had already been similarly decided in Kuieb v. Graves, $^{15}$ an earlier case, but not upon the "entity" theory, for there the court said:

"Nothing can be plainer than that the execution must follow the judgment and be warranted by it. And whether the execution corresponds with the judgment and is warranted by it or not, depends upon the nature and form of the judgment and not upon the effect to be given to it by a plea of former recovery or any other matter dehors the record."

${ }^{23}$ Bitzer v. Shunk and Harper v. Fox, supra, note 2.

"Supra, note II.

${ }^{15} 72 \mathrm{~Pa} .104$ (1872). 
This conclusion was not without precedent, for more than a quarter of a century, prior to this, in Withers v. Livezey, ${ }^{16}$ Justice Kennedy said:

"It seems that a judgment entered by confession of one partner against another without authority from such other, is merely voidable, and, therefore, must be considered valid until vacated or set aside by the court, upon application by the defendant."

In other words, it is a valid partnership matter, unless brought into question by the non-assenting partner, and by him alone, as was said in Grier v. Hood: ${ }^{17}$

"It is only the non-assenting partner that can question the validity of the judgment and this because, as was said in Harper v. Fo.x, the judgment, if permitted to stand, would bind his person and separate estate."

The reasoning in this case is certainly foreign to the "entity" theory of partnership, as expressed by the court in Boyd v. Thompson and Coxe.

As to the distribution of a fund so obtained, no cases dealing squarely with this question can be found; the only mention being made is in the case of York Bank's Appeal. ${ }^{18}$ Here John A. Nevin confessed a judgment on behalf of himself and the firm of Pflieger, Hess and Nevin, in favor of the York Bank. A motion was then made by John Pflieger and Sallie A. Hess to set asicle the judgment as to them, on the ground that they did not join in the execution of the notes on which the judgments were entered, and the court then ordered:

"That the judgment shall not effect or be a lien or incumbrance upon the separate estate, real or personal, of John Pflieger and Sallie A. Hess, two of the members of the firm of Pflieger, Hess \& Nevin, nor upon the partnership account, real or personal, of the firm of Pflieger, Hess \& Nevin, but only upon the separate and individual real or personal estate of John A. Nevin, who confessed the same."

Under this decree, the entire partnership property was sold and Nevin's interest was ascertained to be a little over two thou-

\footnotetext{
${ }^{16}$ I W. \& S. 433 (184I).

${ }^{17} 25 \mathrm{~Pa} .430$ ( 1855 ).

${ }^{18} 36 \mathrm{~Pa} .458$ (1860).
} 
sand five hundred dollars. This fund and no more was demanded by the York Bank as a result of the above decree, and the case then came up before the Supreme Court upon the question whether an improper entry of the Christian names in the judgment index binds a subsequent judgment creditor when he has notice of the prior lien, to which the Supreme Court answered in the affirmative. So well established was the principle of law, that the judgment creditor, under such an execution can only take the individual's interest who confessed the judgment, that the point was not even raised upon argument before the Supreme Court, for no mention of it is made in the report. Therefore, this case, in conjunction with Knicb v. Graves, ${ }^{19}$ clearly establish the principle "that for the purposes of execution, such judgment would be sustained against the goods of the partnership," as quoted in all the subsequent cases, to mean only as a rule of practice and no more, in which the entire partnership property is sold under such judgment, but only the interest of the individual who confessed the judgment is apportioned to such creditor. ${ }^{20}$

All cases dealing with the question of a partnership judgment confessed by one partner only, can be classified under two groups :

r. Those in which plaintiff proceeds to recover directly under his judgment; and,

2. Those in which plaintiff maintains an action in assumpsit under such notes.

And both these groups are governed by a further classification of

(a) Direct ratification by the non-assenting partner; or,

(b) Indirect acquiescence by the non-assenting partner.

With these classifications as a guiding point, it becomes a very easy matter to differentiate the various cases on this subject, with especial reference to those in which the non-assenting partner is held liable.

\footnotetext{
${ }^{19}$ Supra, note 15.

${ }^{30}$ Similar to the practice under the Act of April 8, 1873, P. L. 65, where the judgment is individual and only against one of the partners.
} 
A résumé of the cases leads us to the conclusion that the nonassenting partner is not individually bound by such a confession of judgment. But the judgment itself as an effectual process, is not wholly void, "but merely voidable, and, therefore, must be considered valid until vacated or set aside by the court, upon application by the defendant." 21 And "it is only the non-assenting partner that can question the validity of the judgment."'22

The fact that it may have been given for a partnership debt is immaterial, ${ }^{23}$ unless there is evidence of assent or ratification. ${ }^{24}$ For it has been held that the non-assenting partner may waive this defence, which is peculiarly his, by express ratification or silent acquiescence $;^{25}$ and too long a delay in exercising an option under the partnership contract may be construed as a "ratification." 26 Therefore, we can conclude that the plaintiff must do two things in order to validate such a note.

First: He must perfect the unauthorized confession of judgment, by proving that the non-assenting partner did ratify or acquiesce in such judgment; and,

Second: Having accomplished this, the plaintiff cannot rest here, but must proceed further and show that such note was given for a partnership obligation, as the law does not presume the partnership indebtedness. ${ }^{27}$

The plaintiff, on the other hand, must stand or fall upon the validity of such a note. He cannot raise the curtain and allow the court to view the scene of the transaction. ${ }^{28}$ And this is correct, for the plaintiff had various other opportunities with which to enforce his demands, such as proceeding under his "book accurnt," "cash money loaned" or "partnership promissory notes,"

"Withers v. Livezey, supra, note 16.

$2=$ Grier v. Hood, supra, note I7.

${ }^{23} \mathrm{McCleary}$ v. Thompson, supra, note 3 .

${ }^{24}$ Feighens v. Sobers, $239 \mathrm{~Pa}$. 284 (1913).

${ }^{23}$ Grier v. Hood, supra, note 17. Myers v. Sprenkle, 20 Sup. 549 (I902).

* Evans v. Watts, $192 \mathrm{~Pa}$. I12 (I899).

${ }^{27}$ Ellinger's Appeal, 7 Atl. Rep. I80 (1896). Ellinger's Appeal is much stronger, for in that case both partners did actually sign the note.

${ }^{28}$ Funk v. Young, 24I Pa. 72 (1913). 
as the case may be. But instead, he voluntarily chose to accept this tainted judgment note. With knowledge of the fact that the debtors constituted a partnership, he voluntarily chose to receive a preferential evidence of his indebtedness, from only one of the partners. Surely, if such firm creditor attempted to obtain the highest possible security, the burden was upon him to see that it was done most effectively, and the fact that only one partner signed such judgment note, should lead the court to act with considerable caution.

The foregoing analysis of the cases dealing with the confession of a partnership judgment, by only one partner, we believe, will reconcile all apparent conflict of authorities, and will make the long line of decisions from Girard v. Basse, ${ }^{29}$ down to the recent case of Funk v. Young, ${ }^{30}$ unbroken and uniform. The difficulty injected into the law was caused by the court attempting in Boyd v. Thompson and Coxe To $^{31}$ treat a question of practice as a matter of substantive law. But happily, this case, too, upon a careful analysis trails in line with all the other authorities.

A. E. Hurshman.

Philadelphia.

Supra, note I.

${ }^{30}$ Supra, note 28 .

"Supra, note 4 . 